\title{
Ранняя Византия и гендерные исследования: проблемы и перспективы (по поводу книги: Болгов Н.Н. От гетеры до игуменьи. Женщина в Ранней Византии: мир чувств и жизнь тела. М., 2020)
}

\author{
И.Ю. Ващева \\ Национальный исследовательский \\ Нижегородский государственный университет им. Н.И. Лобачевского, \\ Россия, 603950, г. Нижний Новгород, пр. Гагарина, 23 \\ E-mail: vasheva@mail.ru
}

\begin{abstract}
Аннотация. В данной работе рассматривается круг проблем, связанных с гендерными исследованиями истории Ранней Византии. Импульсом к статье стал выход в 2020 г. научнопопулярной книги Н.Н. Болгова «От гетеры до игуменьи. Женщина в Ранней Византии: мир чувств и жизнь тела». Отмечается, что в отечественной историографии до настоящего времени не сложилось подобного направления исследований. Собственно, и в целом историей Ранней Византии занимаются как основной проблематикой совсем немногие специалисты. Между тем в мировой науке это переходное время в последние десятилетия стало объектом пристального внимания со стороны многочисленных ученых, а количество публикаций приобрело взрывной характер. Сложилось и четко выраженное гендерное направление в изучении истории Поздней античности - Ранней Византии. Книга Н.Н. Болгова, имеющая несомненные достоинства в плане привлечения внимания к данной проблематике, должна послужить также стимулом к развитию исследований такого рода в отечественной византологии и, что не менее важно, обращена к массовому читателю и молодой аудитории. Автору удалось избрать корректную и уважительную интонацию в рамках светской науки при обращении к тематике, имеющей отношение к религиозной традиции.
\end{abstract}

Ключевые слова: гендерные исследования в истории, Ранняя Византия, Поздняя античность, рецензия, отечественная византинистика.

Для цитирования: Ващева И.Ю. 2021. Ранняя Византия и гендерные исследования: Проблемы и перспективы (по поводу книги: Болгов Н.Н. От гетеры до игуменьи. Женщина в Ранней Византии: мир чувств и жизнь тела. М., 2020). Via in tempore. История. Политология, 48 (1): 117-122. DOI: $10.52575 / 2687-0967-2021-48-1-117-122$.

\section{Early Byzantium and gender research: challenges and prospects (about the book: Bolgov N.N. From hetaera to abbess. Woman in Early Byzantium: the world of the senses and the life of the body. M., 2020)}

\author{
Irina Yu. Vascheva \\ N.I. Lobachevsky State University of Nizhni Novgorod - National Research University \\ 23 Gagarin Ave., Nizhni Novgorod, 603950, Russia \\ E-mail: vasheva@mail.ru
}

Annotation. This work examines a range of problems related to gender studies in the history of Early Byzantium. The impetus for the article was the publication in 2020 of the popular science book by N.N. Bolgov «From hetaera to abbess. Woman in Early Byzantium: the world of the senses and the life of 
the body». It is noted that such a direction of research has not yet developed in Russian historiography. Actually, in general, very few specialists deal with the history of Early Byzantium as the main problematic. Meanwhile, this transitional period in recent decades has become the object of close attention from numerous scientists, and the number of publications has become explosive. There is also a clearly expressed gender direction in the study of the history of Late Antiquity - Early Byzantium. The book of N.N. Bolgov, who has undoubted merit in terms of drawing attention to this issue, should also serve as a stimulus for the development of research of this kind in Russian Byzantology and, no less important, is addressed to the general reader and young audience. The author managed to choose a correct and respectful intonation within the framework of secular science when addressing topics related to religious tradition.

Key words: gender studies in history, Early Byzantium, Late antiquity, review, Russian Byzantine studies.

For citation: Vascheva I.Yu. 2021. Early Byzantium and gender research challenges and prospects (about the book: Bolgov N.N. From hetaera to abbess. Woman in Early Byzantium: the world of the senses and the life of the body. M., 2020). Via in tempore. History and political science, 48 (1): 117-122 (in Russian). DOI: 10.52575/2687-0967-2021-48-1-117-122.

In 2020, the publishing house «Lomonosov» published a book by N.N. Bolgov «From hetaera to abbess. Woman in Early Byzantium: the world of the senses and the life of the body». This work is of interest, first of all, because it is, perhaps, the first appearance in Russian popular science literature of work on the gender history of Late Antiquity or early Byzantium. First of all, the theme of the work itself attracts attention. Despite the tremendous interest in the «history of women» in recent times and the real boom in gender studies, there are not many works related to the early Middle Ages and especially early Byzantine history. As the author rightly notes, in world historiography there is a certain corpus of texts in the field of gender history, history of everyday life, social history, history of mentality, etc., created in recent decades by Byzantinists [Patlagean, 1976; Galatariotou, 1984-1985; Laiou 1981, 1992, 1993; Vogt, 1995; Arjava 1996; Garland, 2006, et al.]. Russian science in this direction is taking only the first steps [Болгов, 2020, p. 5-6]. For this reason, this book, although it has a popular scientific character, certainly deserves attention and has indisputable novelty and relevance, filling a significant gap in Russian historiography.

The period of the 4 th -7 th centuries, which is discussed in the book, regardless of the name «early Byzantine» or «late antique», deserves special attention. This is the period of the most complex transformations in all spheres of life: the era of cardinal changes in the economic order, political perturbations, social upheavals, transformation of the entire system of values and mental attitudes, etc. Scientific comprehension of the period 4th -7 th centuries as an independent late antique era with its own specificity, began relatively recently. As for the position of a woman and her mentality in this era, in an era of paradigm change, the novelty and significance of this issue does not cause the slightest doubt.

Gender history, private life, history of mentality and history of corporality, history of sexuality, history of everyday life in Early Byzantium can hardly be called a well-studied field. Currently, these studies are in great demand, but they are just beginning to develop in Russian Byzantine studies.

As stated in the annotation, the work provides an outline of the history of the private life of an early Byzantine woman, but this book not only paints a broad panorama of the life of an early Byzantine woman, but also raises very serious and complex scientific problems. Each chapter, in fact, poses a separate scientific problem that requires serious research and scientific understanding.

The first chapter, which immerses the reader in the world of the private life of an early Byzantine woman, refers the reader to the history of the body and corporeality, so discussed in 
modern humanitarian knowledge. It must be said that the attitude of the Christian church fathers to the body in general and the female body as a source of temptation in particular, theological reasoning about the nature of women in literature has been repeatedly discussed. However, the author not only shows the complexity and ambivalence of the Christian attitude towards women and her corporeality, but also perfectly shows the role of classical ancient traditions and stereotypes in the everyday life of the late antique society.

The second chapter, dealing with the history of the mentality of early Byzantine society, tells «about a mental upheaval and a radical change in the axiological scale due to the Christianization of East Roman society» [Болгов, 2020, p. 78]. As the author shows, this mental upheaval, a revolution in the system of values, radically changed the concepts of good and evil and the boundaries of what is permitted when the ancient paradigms of civilization were replaced by Christian ones. Obviously, the same «mental upheaval» leads women to rethink their sexuality, gender, and gender behavior and forces them to move away from traditional family values that have been formed for centuries and firmly entrenched in the minds of asceticism and monastic practices. The work perfectly shows this scrapping, a change in value orientations, but it does not give a clear and comprehensive answer to the question: "Why is this happening?», which makes the reader think over and over again about the realities of that time. In general, the chapter raises very serious problems of concern to many scientists.

Chapter 3 shows the various social roles of the early Byzantine woman in a wide range from hetaera to nun, shows very unusual female practices associated with gender refusal, which were widespread in the period of the $4^{\text {th }}-7$ th centuries. At the same time, a fair reservation is made that, as a rule, extreme or brightest manifestations of this or that phenomenon fall on the pages of sources, and the «mass» flow requires additional efforts to detect and analyze it.

The fourth chapter presents a whole gallery of female portraits and destinies - in the predominantly «male history» of Early Byzantium. For a long time, the attention of historians was attracted only by the fates of individual, most famous Byzantine women, mainly empresses, for example, the figures of the Empress Irina or the wife of Emperor Justinian Theodora. This work, partly following this tradition due to the nature of the available sources, builds in front of the reader a whole series of portraits of representatives of the political elite of Byzantium, and most importantly - tells about the private life and worldview of an ordinary woman, about those relationships that were considered the norm in early Byzantine society and often remained unspoken, not exposed.

The fifth chapter is devoted to the history of everyday life, telling about the history of costume, types of dwellings, food, dishes and other everyday realities that made up the everyday life of a Byzantine woman. Obviously, it took a lot of work to collect these smallest details, scattered in a huge number of various sources, and put them into a single picture that adequately reflects the subtle world of early Byzantine realities. And if in world historiography there have been publications such as Koukales' eight-volume book [Koukales, 1947-1957] for quite a long time, in Russian historiography such works are a great rarity.

The sixth chapter examines the gender aspects of the legal culture of early Byzantium. As the author points out, «the law most fully determines the social status of the sexes, their property characteristics and, therefore, reflects the existing gender system in its normative refraction» [Болгов, 2020, p. 189].

Thus, this book poses the most complex and acutely urgent scientific problems today and examines them on the basis of early Byzantine material.

The author relies on a wide range of sources of a very different nature [Болгов, 2020, p. 7-12], to which references are made, attracts a vast layer of modern scientific research, of which the works of Elizabeth Castelli, S.E. Harvey, Av. Cameron, J. Cloak, R. Webb and others, many of whom are little known to the Russian reader [Castelli 1986, 1991, 2001; Harvey 1990; Cameron, Kuhrt, 1993; Cloke, 1993; Webb, 1997, 2002, etc.], consistently reveals in various 
spheres of a woman's private life the dichotomy «continuity - discontinuity», which largely determines the nature of the complex and contradictory era of the 4th -7 th centuries.

The methodological approaches used in this book are new and relevant for Russian Byzantine studies, while in foreign ones they became widespread only in the last decades of the Twentieth Century.

The fact that the author was able to explain these complex problems and discussions to the young reader, to whom the publishing house «Lomonosov» is oriented, deserves special attention, to the reader who often does not have a university education, to tell briefly and simply about the complex.

Also, in terms of the presentation of the material and the style, this work evokes certain associations with the famous book by A.P. Rudakov [Rudakov, 1996] (although this book, due to its release in the situation of 1917 , had limitations in volume).

At the same time, it is possible to note some remarks to this work, which are inevitable in studies of this kind. For example, extremely interesting material on the development of female monasticism is given, unfortunately, only on the example of Egypt and Palestine, while Syrian monasticism or the development of monasteries in other regions of the empire is not at all affected.

In addition, in the introduction on p. 13 casually mentions that «monuments of illustrative art, such as the mosaics of Ravenna and Constantinople, book miniatures, etc., made it possible to draw observations and conclusions regarding the external representation of a woman's inner world (clothing, jewelry, etc.)». However, the publication, unfortunately, does not contain substantive illustrations and does not allow the reader to build a visual series himself, which is very significant for this topic.

Finally, it seems to us that it is not very successful and not entirely justified to use quotations from Berdyaev and other Russian philosophers [Болгов, 2020, p. 31], which does not so much explain the realities of the early Byzantine world, as it leads to the side of discussions around controversial issues of Russian theological and philosophical thought of the 19th - early 20th centuries.

It can be noted that some of the works and names of researchers mentioned in the text are absent from the list of references attached to the work. So, apparently, during editorial work, all publications in foreign languages were omitted, and only in Russian were left.

However, in general, these remarks are not of a fundamental nature and do not reduce the overall positive impression of the book.

So, this work is the first edition of this kind in modern Russian historical science. A very interesting and relevant topic, an appeal to serious scientific problems, and, at the same time, an easy-to-understand, very lively language and writing style will certainly interest the widest audience. The book is written in the best traditions of popular science literature and combines the necessary depth of approach to the topic, uniqueness of information and fascinating presentation of the material.

Reflecting on the problems and prospects, it can be noted that domestic Byzantine studies in the future, undoubtedly, could intensify its efforts towards expanding the methodological arsenal, in particular, mastering gender issues, while preserving its best traditions. The early Byzantine period provides ample research opportunities for this.

\section{Список литературы}

1. Болгов Н.Н. 2020. От гетеры до игуменьи. Женщина в Ранней Византии: мир чувств и жизнь тела. М., Ломоносов, 208.

2. Репина Л.П. 2001. Гендер в истории: проблематика и методология исследований. В кн.: Теория и методология гендерных исследований. М., МЦГИ/МВШСЭН: 351-365.

3. Рудаков А.П. 1996. Очерки византийской культуры по данным греческой агиографии. СПб., Алетейя, 288. 
4. Arjava A. 1996. Women and Law in Late Antiquity. Oxford, Clarendon Press, 338.

5. Cameron Av., Kuhrt A. (ed.). 1993. Images of Women in Antiquity. Detroit, Wayne State univ. Press/Routledge, 356.

6. Castelli E. 1991. «I Will Make Mary Male»: Pieties of the Body and Gender Transformation of Christian Women in Late Antiquity. In: Body guards: The cultural politics of gender ambiguity, Jan 1. New York, Routledge: 29-49.

7. Castelli E.1986. Virginity and its Meaning for Women's Sexuality in Early Christianity. In: Journal of Feminist Studies in Religion. 2-1: 61-88.

8. Castelli E. 2001. Women, Gender, Religion: A Reader. Edited with the assistance of Rosamond C. Rodman. New York, Palgrave/St. Martin's Press, 550.

9. Cloke G. 1993. Women in Late Antiquity. Pagan and Christian Life-styles. Oxford, Clarendon Press, 158.

10. Galatariotou C. 1984-1985. Holy Women and Witches: Aspects of Byzantine Conceptions of Gender. In: Byzantine and Modern Greek Studies. Vol. 9: 55-94.

11. Garland L. 2006. Byzantine Women: Varieties of Experience 800-1200. London, Ashgate, 226.

12. Harvey S.A. 1990. Women in Early Byzantine Hagiography: Reversing the Story. In: Women's Strength: historical perspectives on women in Christianity. Ed. by L.L. Coon, K.J. Haldane, E.W. Sommer. Charlottesville, Univ. Press of Virginia: 46-50.

13. Koukales P. 1947-1957. The Private Life of the Byzantines [Byzantinon bios kai politismos]. 8 vols. Athens: Institut Francais.

14. Laiou A.E. 1992.Gender, Society and Economic Life in Byzantium. Brookfield, Variorum Coll. Studies, 268.

15. Laiou A.E.1993. Sex, Consent and Coercion in Byzantium. In: Consent and Coercion to Sex and Marriage in Ancient and Medieval Societies. Ed. A.E. Laiou. Washington, D. C.: 109-221.

16. Laiou A.E. 1981. The Role of Women in Byzantine Society. In: Jahrbuch der Österreichischen Byzantinistik. Bd. 31,1: 233-260.

17. Patlagean E. 1976. L'histoire de la femme déguisée en moine et l'évolution de la sainteté féminine à Byzance. In: Studi Medievali. Ser. 3. Vol. 17: 597-625 (in French).

18. Vogt K. 1995. «The Woman Monk»: a Theme in Byzantine Hagiography. In: Greece \& Gender. Ed. by B. Berggreen, N. Marinatos. Bergen, Norwegian Institute at Athens: 141-148.

19. Webb R. 2002. Female Performers Entertainers in Late Antiquity. In: Greek and Roman Actors: Aspects of an Ancient Profession. Ed. P. Easterling, E. Hall. Cambridge, Cambridge University Press: 282-303.

20. Webb R. 1997. Salome's Sisters: the Rhetoric and Realities of Dance in Late Antiquity and Byzantium. In: Women, Men and Eunuchs: Gender in Byzantium. Ed. L. James. London; New York, Routledge: 119-148.

\section{References}

1. Bolgov N.N. 2020. Ot getery do igumen'i. Zhenshchina v Rannej Vizantii: mir chuvstv I zhizn' tela [From hetaera to abbess. Woman in Early Byzantium: the world of the senses and the life of the body]. Moscow, Lomonosov, 208 (In Russian).

2. Repina L.P. 2001. Gender v istorii: problematika I metodologiya issledovanij [Gender in History: Problems and Research Methodology]. In: Teoriya i metodologiya gendernyh issledovanij [Theory and methodology of gender studies]. Moscow: Moscow center for gender studies/Moscow Higher School Social and Economic Sciences: 351-365 (in Russian).

4. Arjava A. 1996. Women and Law in Late Antiquity. Oxford, Clarendon Press, 338.

5. Cameron Av., Kuhrt A. (ed.). 1993. Images of Women in Antiquity. Detroit, Wayne State univ. Press/Routledge, 356.

6. Castelli E. 1991. «I Will Make Mary Male»: Pieties of the Body and Gender Transformation of Christian Women in Late Antiquity. In: Body guards: The cultural politics of gender ambiguity, Jan 1. New York, Routledge: 29-49.

7. Castelli E.1986. Virginity and its Meaning for Women's Sexuality in Early Christianity. In: Journal of Feminist Studies in Religion. 2-1: 61-88. 
8. Castelli E. 2001. Women, Gender, Religion: A Reader. Edited with the assistance of Rosamond C. Rodman. New York, Palgrave/St. Martin's Press, 550. don Press, 158.

9. Cloke G. 1993. Women in Late Antiquity. Pagan and Christian Life-styles. Oxford, Claren-

10. Galatariotou C. 1984-1985. Holy Women and Witches: Aspects of Byzantine Conceptions of Gender. In: Byzantine and Modern Greek Studies. Vol. 9: 55-94.

226.

11. Garland L. 2006. Byzantine Women: Varieties of Experience 800-1200. London, Ashgate,

12. Harvey S.A. 1990. Women in Early Byzantine Hagiography: Reversing the Story. In: Women's Strength: historical perspectives on women in Christianity. Ed. by L.L. Coon, K.J. Haldane, E.W. Sommer. Charlottesville, Univ. Press of Virginia: 46-50.

13. Koukales P. 1947-1957. The Private Life of the Byzantines [Byzantinon bios kai politismos]. 8 vols. Athens: Institut Francais.

14. Laiou A.E. 1992.Gender, Society and Economic Life in Byzantium. Brookfield, Variorum Coll. Studies, 268.

15. Laiou A.E.1993. Sex, Consent and Coercion in Byzantium. In: Consent and Coercion to Sex and Marriage in Ancient and Medieval Societies. Ed. A.E. Laiou. Washington, D. C.: 109-221.

16. Laiou A.E. 1981. The Role of Women in Byzantine Society. In: Jahrbuch der Österreichischen Byzantinistik. Bd. 31,1: 233-260.

17. Patlagean E. 1976. L'histoire de la femme déguisée en moine et l'évolution de la sainteté féminine à Byzance. In: Studi Medievali. Ser. 3. Vol. 17: 597-625 (in French).

18. Vogt K. 1995. «The Woman Monk»: a Theme in Byzantine Hagiography. In: Greece \& Gender. Ed. by B. Berggreen, N. Marinatos. Bergen, Norwegian Institute at Athens: 141-148.

19. Webb R. 2002. Female Performers Entertainers in Late Antiquity. In: Greek and Roman Actors: Aspects of an Ancient Profession. Ed. P. Easterling, E. Hall. Cambridge, Cambridge University Press: 282-303.

20. Webb R. 1997. Salome's Sisters: the Rhetoric and Realities of Dance in Late Antiquity and Byzantium. In: Women, Men and Eunuchs: Gender in Byzantium. Ed. L. James. London; New York, Routledge: 119-148.

\section{ИНФОРМАЦИЯ ОБ АВТОРЕ}

Ващева Ирина Юрьевна, доктор исторических наук, профессор кафедры средневековых цивилизаций Института международных отношений и мировой истории Нижегородского государственного университета им. Н.И. Лобачевского, г. Нижний Новгород, Россия

\section{INFORMATION ABOUT THE AUTHOR}

Irina Yu. Vascheva, doctor of historical sciences, professor of the Department of medieval civilizations of Institute of International Relations and World History, N.I. Lobachevsky State University of Nizhni Novgorod - National Research University, Nizhni Novgorod, Russia 